\title{
Comparison of multilocus RFLPs and PCR-based marker systems for genetic analysis of the silkworm, Bombyx mori
}

\author{
J. NAGARAJU*†, K. DAMODAR REDDY $\$$, G. M. NAGARAJA $\$$ \\ \& B. N. SETHURAMAN \\ $\dagger$ Laboratory of Molecular Genetics, Centre for DNA Fingerprinting and Diagnostics, ECIL Road, Nacharam, \\ Hyderabad, 500 076, India and $\$$ Seribiotech Research Laboratory, No. 8, West of Chord Road, Bangalore-560 086, India
}

\begin{abstract}
The utility of multilocus RFLPs and three PCR-based techniques, Random Amplified Polymorphic DNA (RAPD), Inter-Simple Sequence Repeat-PCR (ISSR-PCR) and simple sequence repeats (SSRs) for genetic characterization was examined using 13 diverse silkworm strains. All four approaches successfully discriminated the 13 silkworm varieties but differed in the amount of polymorphism detected. The usefulness of each system was examined in terms of number of loci revealed (effective multiplex ratio, EMR) and the amount of polymorphism detected (diversity index, DI). For example, the six multilocus RFLP probes produced 180 products of which $97 \%$ were polymorphic; 15 SSR loci gave rise to an average of 8 alleles each, of which $86 \%$ were polymorphic. The ISSR-PCR produced 39 fragments of which $76.98 \%$ were polymorphic. The highest diversity index was observed for ISSRPCR (0.957) and the lowest for RAPDs (0.744). The RAPD, ISSR-PCR and RFLP assays clearly separated the diapausing and non-diapausing silkworm varieties. These results are discussed in terms of choice of appropriate marker technology for different aspects of silkworm genome analysis.
\end{abstract}

Keywords: EMR, ISSR-PCR, non-diapausing, RAPD, RFLP, SSR.

\section{Introduction}

The detection and exploitation of naturally occurring DNA sequence polymorphisms are among the most significant developments in molecular biology. Polymorphic genetic markers have wide potential applications in animal and plant improvement programmes as a means for varietal and parentage identification, evaluation of polymorphic genetic loci affecting quantitative economic traits, and genetic mapping. RFLPs have been used extensively for genetic studies (Bishop \& Skolnick, 1980; Botstein et al., 1980), molecular mapping and genetic improvement programmes. However, the technical complexity of performing RFLP analysis coupled with the widespread use of short-lived radioisotopes for detection have prompted researchers to look for alternative methods.

The advent of the PCR has resulted in the development of a large number of molecular techniques, which offer an effective alternative to the hybridization methods of RFLP analysis. PCR-based approaches use only small quantities of DNA, avoid DNA blotting and use

*Correspondence. E-mail: jnagaraju@mailcity.com; jnagaraju@www. cdfd.org.in of radioactivity, and are amenable to automation. The RAPD method described by Williams et al. (1990) and Welsh \& McClelland (1990) generates PCR products by annealing to randomly distributed homologous target sites of the template DNA. This technique mostly generates dominant markers, although length polymorphisms caused by insertions/deletions can also occur at low frequencies. Because of its relative simplicity, RAPD technology is being extensively used in genetic analysis of various plant and animal species. However, limitations in the applications of RAPDs such as the dominant nature of the markers, chance co-migration of bands at different loci, and requirement for stringent protocol standardization to ensure reproducibility have also been encountered (Black, 1993).

Another class of PCR-based markers, the microsatellites, takes advantage of the abundant and ubiquitously distributed simple sequence repeats (SSRs) in the eukaryotic genome (Hamada et al., 1982; Weber \& May, 1989; Dietrich et al., 1992). The variation in repeat number can be visualized as differences in the length of PCR-amplified products (Tautz et al., 1986; Tautz \& Renz, 1984). Analysis of SSRs requires prior characterization of sequences flanking the repeats to allow the design of primers for PCR amplification. SSRs are 
codominant markers and can reveal multiple alleles at a single locus. The technique is robust in that it is highly reproducible and the primer sequence information can be exchanged between laboratories.

As PCR technology finds increased use in genetic analysis, novel variations of this technique are emerging which promise precision, economy and speed (Wu et al., 1994; Zietkiecwicz et al., 1994; Vos et al., 1995). One such alternative is SSR-anchored PCR (or ISSR-PCR for Inter-Simple Sequence Repeat PCR) in which a stretch of microsatellite sequence, which also contains a short oligonucleotide 'anchored' sequence either at the $5^{\prime}$ or $3^{\prime}$ end, is targeted to the template DNA in question and upon PCR amplification, inter-repeat genomic regions can be visualized as discrete products (Zietkiecwicz et al., 1994). The technique generates a large number of markers by simultaneously targeting multiple microsatellite loci and allows screening of a large number of samples in a single gel.

The silkworm, Bombyx mori, is an excellent model genetic system and an important insect economically. Genome analysis has been initiated in the silkworm with the objectives of obtaining genetic maps using different marker systems: RFLPs (Shi et al., 1995), RAPDs (Promboon et al., 1995) and RAPD double primers (Yasukochi, 1998), and to characterize genetic diversity by DNA fingerprinting using ISSR-PCR (Reddy et al., 1999a), a heterologous minisatellite probe, Bkm (Nagaraju et al., 1995; Sharma et al., 1998), microsatellite loci (Reddy et al., 1999b) and RAPDs (Nagaraja \& Nagaraju, 1995). In addition, more than 3000 silkworm strains which represent a repertoire of genetic differences for various complex traits such as silk fibre length, larval growth and resistance to disease, are being maintained in different countries. Molecular genetic analysis of such complex traits using DNA markers would provide valuable tools for economic improvement of this insect.

In the present study, we examined multilocus RFLPs and three PCR-based marker assays, RAPDs, SSRs and ISSR-PCR for evaluating the genetic diversity in certain representative strains of silkworm. We report results here using 13 diverse silkworm strains with a view to comparing their effectiveness in detecting genetic variation and to determine the utility of each system with respect to technical and financial considerations.

\section{Materials and methods}

\section{Silkworm strains and DNA extraction}

Thirteen diverse silkworm genotypes were used in the present study. The characteristics of the genotypes are listed in Table 1. All DNA extractions were performed

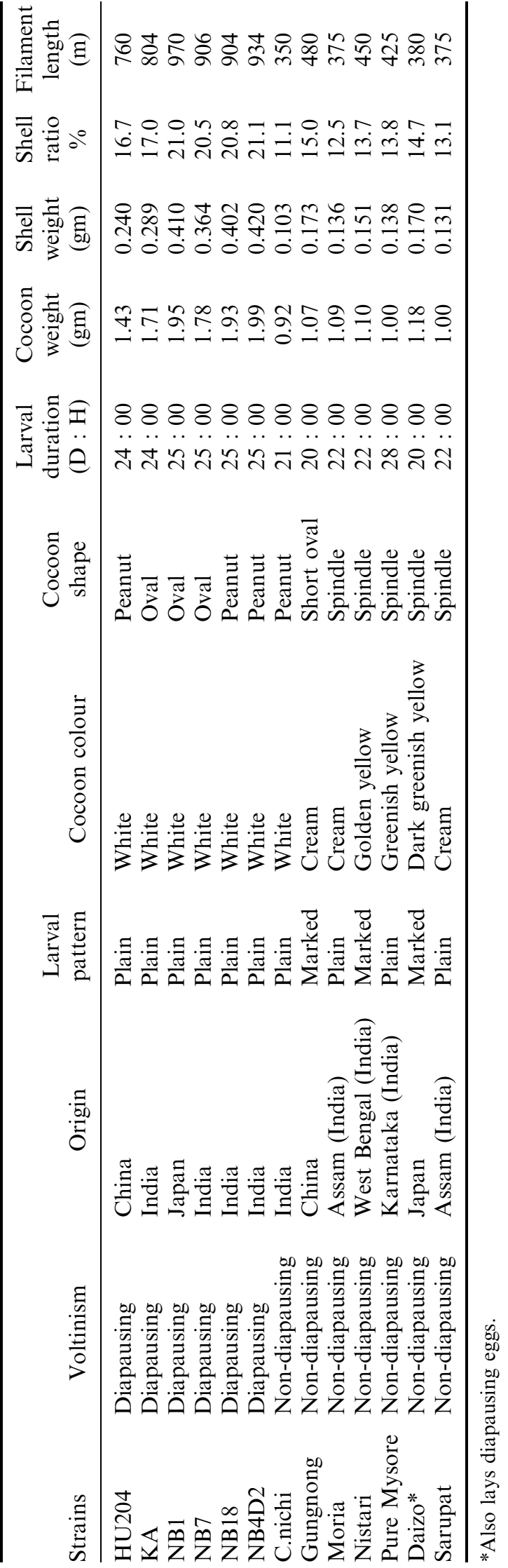


on liquid nitrogen frozen silk glands using the method already described (Nagaraja \& Nagaraju, 1995).

\section{RFLP analysis}

High molecular weight genomic DNA was isolated from posterior silk glands of instar 5 larvae pooled from 10 individuals per strain. 10-12 $\mu \mathrm{g}$ of DNA was digested to completion with restriction enzymes, EcoRV or BamHI (New England Biolabs) depending on the probe (Table 2). Digested samples were fractionated by $0.8 \%$ agarose gel in TAE buffer and southern transferred on to a nylon membrane (Hybond-N, Amersham) by vacuum blotting (Pharmacia Biotech). The membranes were baked at $80^{\circ} \mathrm{C}$ for $2 \mathrm{~h}$. The anonymous multilocus probes used in the present study were obtained from a PstI subgenomic library. The probes were labelled with $\alpha^{32} \mathrm{P}$ dCTP using a random primer labelling kit (Amersham, UK). All other operations including pre-hybridization, hybridization and washing were performed according to Sambrook et al. (1989). The membranes were then exposed to X-ray film for 1-3 days. Autoradiograms were examined visually to score the hybridized bands.

\section{RAPD analysis}

RAPD analysis was carried out on 13 silkworm strains using 10-mer oligonucleotide primers (listed in Table 2) obtained from Operon Technologies, USA as described by Nagaraja \& Nagaraju, (1995).

\section{SSR analysis}

Simple Sequence Repeat (SSR) polymorphism analysis was performed using 15 primer sets for different microsatellite motifs listed in Table 2 on 13 silkworm genotypes. The SSR loci have been cloned and characterized from the subgenomic library constructed from the Nistari silkworm strain as described by Reddy et al. (1999b). PCR was performed using a Perkin Elmer 480 Thermal cycler. Typical PCR reactions $(20 \mu \mathrm{L})$ were performed in $10 \times$ PCR buffer $(500 \mathrm{~mm} \mathrm{KCl}, 100 \mathrm{~mm}$ Tris- $\mathrm{HCl}$ and $1.0 \%$ Triton X-100), $1 \mathrm{~mm}$ of dATP, dGTP, dTTP each and $0.25 \mathrm{~mm} \mathrm{dCTP,} 4 \mu \mathrm{M}$ of each primer, $2 \mu \mathrm{Ci}$ of $\alpha^{32} \mathrm{P}$-dCTP $(1000 \mathrm{Ci} / \mathrm{mmol}), 1$ unit of Taq DNA polymerase (Perkin-Elmer Cetus) and $20 \mathrm{ng}$ of template DNA. Different concentrations of $\mathrm{MgCl}_{2}$ (1-4 mM) were used depending on the locus amplified. Samples were overlaid with $20 \mu \mathrm{L}$ of mineral oil. PCR cycles for microsatellite loci included a $2-\mathrm{min}$ at $94^{\circ} \mathrm{C}$ initial denaturation step, followed by 30 cycles of $94^{\circ} \mathrm{C}$ $(30 \mathrm{~s})$, annealing at $42^{\circ} \mathrm{C}$ to $55^{\circ} \mathrm{C}(30 \mathrm{~s})$ and extension at $72^{\circ} \mathrm{C}(45 \mathrm{~s})$. The final elongation step was extended to
$10 \mathrm{~min}$ at $72^{\circ} \mathrm{C}$. Aliquots of amplified DNA from individual PCR reactions were mixed with formamide stop solution (95\% formamide, $20 \mathrm{~mm}$ EDTA, 0.05\% Bromophenol blue and $0.05 \%$ xylene cyanol in the ratio of $3: 2)$. Samples $(4 \mu \mathrm{L})$ were denatured at $75^{\circ} \mathrm{C}$ for $2 \mathrm{~min}$, chilled on ice and electrophoresed on standard sequencing gels $(6 \%$ acrylamide, $8 \mathrm{~m}$ urea, $1 \times \mathrm{TBE}$ (89 mм Tris-borate, 2 mm EDTA, pH 8.3). An M13 sequence ladder was used on each gel as a size marker. After electrophoresis, the gels were fixed for $2 \times 20 \mathrm{~min}$ with $10 \%$ acetic acid, dried at room temperature and exposed to X-ray film for 4-12 h.

\section{SSR-anchored PCR}

A range of primers was synthesized on an Applied Biosystems DNA synthesizer based on the core repeats, anchored either at the $5^{\prime}$ end or $3^{\prime}$ end (Table 2). These primers were used to screen the silkworm strains as described by Reddy et al. (1999a). The PCR reaction was carried out in a total volume of $20 \mu \mathrm{L}$ containing $20 \mathrm{ng}$ of genomic DNA, $10 \times$ PCR buffer $(500 \mathrm{~mm} \mathrm{KCl}, 100 \mathrm{~mm}$ Tris- $\mathrm{HCl}$ and $1.0 \%$ Triton X-100), $10 \times$ dNTP stock $(2 \mathrm{~mm}), 10 \mu \mathrm{M}$ of anchored primer (a mixture of $1: 4$ labelled primer using $\gamma^{32} \mathrm{P}$ ATP $(6000 \mathrm{Ci}$, BRIT, JONAKI, Hyderabad) and cold primer. The samples were overlaid with $10 \mu \mathrm{L}$ of mineral oil and processed using a PerkinElmer Cetus model 480 Thermal Cycler. The cycling conditions were: initial denaturation of $2 \mathrm{~min}$ at $94^{\circ} \mathrm{C}$, 27 cycles of $30 \mathrm{~s}$ at $94^{\circ} \mathrm{C}, 45 \mathrm{~s}$ at $52^{\circ} \mathrm{C}$ and $2 \mathrm{~min}$ at $72^{\circ} \mathrm{C}$, and one last cycle of $7 \mathrm{~min}$ at $72^{\circ} \mathrm{C}$. On completion of the PCR, the reaction was stopped using $6 \mu \mathrm{L}$ of stop solution as indicated previously. A $4 \mu \mathrm{L}$ aliquot of each of the reaction products was denatured at $75^{\circ} \mathrm{C}$ for $2 \mathrm{~min}$, chilled on ice and then run on a sequencing gel containing $6 \%$ polyacrylamide, $8 \mathrm{M}$ urea and $1 \times \mathrm{TBE}$, at $1500 \mathrm{~V}$ of constant power for $10-12 \mathrm{~h}$. Sequencing reactions of M13mp18 DNA were used as molecular weight standards to determine the exact length of the PCR products. After electrophoresis, gels were fixed for $2 \times 20 \mathrm{~min}$ in $10 \%$ glacial acetic acid, dried at room temperature and applied to autoradiographic film for $2-10 \mathrm{~h}$ at room temperature.

\section{Data analysis}

In the RFLP assay, hybridized bands and in PCR-based assays specific amplified products that were reproducible in successive amplifications were identified as marker bands defined by their molecular weights estimated from the size standards. Polymorphisms were scored for presence (1) or absence ( 0 ) of the bands. The proportion 
Table 2 A list of RAPD, ISSR and SSR primers and multilocus RFLP probes used in the study

\begin{tabular}{|c|c|c|c|c|c|}
\hline Primer code & Primer sequence $\left(5^{\prime}\right.$ to $\left.3^{\prime}\right)$ & $\begin{array}{c}\text { Annealing } \\
\text { temperature }\left({ }^{\circ} \mathrm{C}\right)\end{array}$ & $\begin{array}{l}\text { No. } \\
\text { alleles }\end{array}$ & $\begin{array}{l}\text { Allele } \\
\text { size }\end{array}$ & Heterozygosity \\
\hline \multicolumn{6}{|l|}{ RAPD: } \\
\hline OPA & 20 numbers & 36 & & & \\
\hline OPB & 20 numbers & 36 & & & \\
\hline \multicolumn{6}{|l|}{ ISSR: } \\
\hline 5'-anchored-SSR & $\mathrm{BDB}(\mathrm{CA}) 7$ & 52 & & & \\
\hline & VHVG(TG)7 & 52 & & & \\
\hline & DBDA(CA)7 & 52 & & & \\
\hline & HVH(TG)7 & 52 & & & \\
\hline 3'-anchored-SSR & (GT) $8 \mathrm{RG}$ & 52 & & & \\
\hline & (GT)8RTCY & 52 & & & \\
\hline \multicolumn{6}{|l|}{ SSR: } \\
\hline sat158 & $\begin{array}{l}\text { cttccagacaaccattagat } \\
\text { cagcatccatccttatttat }\end{array}$ & 49 & 11 & $190-246$ & 0.76 \\
\hline sat211 & $\begin{array}{l}\text { gatcgaactacgcaattacg } \\
\text { cagcatccatccttatttat }\end{array}$ & 49 & 6 & $6-146$ & 0.89 \\
\hline sat256 & $\begin{array}{l}\text { attgcctcggacaggagtgt } \\
\text { tgtgaggacaggccgtta }\end{array}$ & 53 & 7 & $111-194$ & 0.82 \\
\hline sat346 & $\begin{array}{l}\text { gaagacagagcgaagtgga } \\
\text { atggattcctgctggtagat }\end{array}$ & 53 & 6 & 139-189 & 0.83 \\
\hline sat892 & $\begin{array}{l}\text { caataaatgcttacgagtttaa } \\
\text { tatcggtagttccttgactt }\end{array}$ & 47 & 3 & $175-187$ & 0.66 \\
\hline sat951 & $\begin{array}{l}\text { attgtaaccgatttgagaga } \\
\text { attcgcacaataagttcact }\end{array}$ & 48 & 5 & $107-122$ & 0.68 \\
\hline sat962 & $\begin{array}{l}\text { cataataaataaataataat } \\
\text { tgtagtgggatagtcagtat }\end{array}$ & 42 & 6 & $108-114$ & 0.78 \\
\hline sat1013 & $\begin{array}{l}\text { aacagatgctgcggactggt } \\
\text { tgccattcacaatacaacat }\end{array}$ & 50 & 5 & $135-162$ & 0.80 \\
\hline sat1411 & $\begin{array}{l}\text { gaatgttctgctggtgg } \\
\text { taatgtttttatactttattatatg }\end{array}$ & 45 & 8 & $109-162$ & 0.68 \\
\hline sat1423 & $\begin{array}{l}\text { ctttcgatcaccgcgttctc } \\
\text { cgctacgaaataccattatctgaca }\end{array}$ & 55 & 9 & $130-176$ & 0.82 \\
\hline sat1893 & $\begin{array}{l}\text { aatgcagaatcgtaattttt } \\
\text { tttgaccacagacaataagc }\end{array}$ & 45 & 7 & $98-158$ & 0.85 \\
\hline sat 2550 & $\begin{array}{l}\text { ggtccettgaaactgegat } \\
\text { cagagacetgecggttgtcgtt }\end{array}$ & 53 & 9 & $121-168$ & 0.87 \\
\hline sat2604 & $\begin{array}{l}\text { gctcgccatatgcaatcctc } \\
\text { cgtcattgcettcatttcagttc }\end{array}$ & 53 & 8 & $143-186$ & 0.86 \\
\hline sat2763 & $\begin{array}{l}\text { acgcgetctacaaaataccatta } \\
\text { gatcaccggttctgctctcg }\end{array}$ & 53 & 17 & $105-179$ & 0.90 \\
\hline sat3513 & $\begin{array}{l}\text { cgcaattctgtattagataa } \\
\text { aaaggtattattcttattcg }\end{array}$ & 46 & 6 & $134-223$ & 0.84 \\
\hline \multirow[t]{7}{*}{ RFLP: } & Probe number & \multicolumn{4}{|c|}{ Enzyme used for digestion } \\
\hline & $\mathrm{pBmN} 138$ & EcoRV & & & \\
\hline & pBmN 319 & EcoRV & & & \\
\hline & $\mathrm{pBmN} 445$ & $E c o \mathrm{RI}$ & & & \\
\hline & pBmN 803 & BamHI & & & \\
\hline & pBmN 948 & EcoRV & & & \\
\hline & pBmN 966 & EcoRV & & & \\
\hline
\end{tabular}

(C) The Genetics Society of Great Britain, Heredity, 86, 588-597. 
of bands that were shared between any two screened varieties averaged over the total number of loci was used as the measure of similarity for all marker types. This corresponds to using simple matching coefficients of similarity. The data was analysed using $\mathrm{Nei}$ and $\mathrm{Li}$ coefficients (Nei \& Li, 1979).

Cluster analyses were based on similarity matrices using the unweighted pair group method analysis (UPGMA) program in WIN BOOT software (Yap \& Nelson, 1996). The relationships between varieties were represented graphically in the form of dendrograms. In order to determine the utility of each of the marker systems, diversity index (DI), effective multiplex ratio (EMR) and marker index (MI) were calculated according to Powell et al. (1996).

DI for genetic markers was calculated from the sum of the squares of allele frequencies:

$\mathrm{DI}_{\mathrm{n}}=1 \quad \sum p i^{2}$

where 'pi' is the allele frequency of the ith allele.

The arithmetic mean heterozygosity, $\mathrm{Di}_{\mathrm{av}}$, was calculated for each marker class:

$\mathrm{Di}_{\mathrm{av}}=\sum \mathrm{Di}_{\mathrm{n} / \mathrm{n}}$

where ' $\mathrm{n}$ ' is the number of markers (loci) analysed.

The DI for polymorphic markers is:

$\left(\mathrm{Di}_{\mathrm{av}}\right)_{\mathrm{p}}=\sum \mathrm{Di}_{\mathrm{n}} / \mathrm{n}_{\mathrm{p}}$

where ' $n_{p}$ ' is the number of polymorphic loci and $n$ is the total number of loci.

EMR (E) is the product of the fraction of polymorphic loci and the number of polymorphic loci for an individual assay.

$\operatorname{EMR}(\mathrm{E})=\mathrm{n}_{\mathrm{p}}\left(\mathrm{n}_{\mathrm{p}} / \mathrm{n}\right)$

MI is defined as the product of the average diversity index for polymorphic bands in any assay and the EMR for that assay, $\mathrm{MI}=\mathrm{DI}$ avp $\times \mathrm{E}$.

\section{Results}

The multilocus RFLPs and all three PCR assays reliably discriminated among the 13 silkworm varieties examined (Fig. 1a-1d). However, each of the PCR and multilocus RFLP-based techniques differed in the type and degree of polymorphism detected. Moreover, the total number of assays varied for each of the marker systems. It was 40 primers for RAPDs, 15 primer pairs for dinucleotide SSR loci, only six anchored primers for ISSR-PCR and six multilocus probes for RFLPs (Table 2). As a result, the total number of bands scored for each of the assays varied, ranging from 122 for SSR to 239 for ISSR-PCR. In the RAPD analysis, using 40 random primers, a total of 216 discrete amplified products (5.4 bands/primer) were obtained, of which 204 were polymorphic $(94.4 \%)$ in at least one pair-wise comparison between silkworm varieties, and the remaining 12 were monomorphic. Four $5^{\prime}$-anchored and two $3^{\prime}$-anchored SSRs revealed a total of 239 amplification products (39.8 bands/primer) of which 184 were polymorphic $(76.98 \%)$. Primer pairs designed for 15 SSR loci yielded 122 PCR products (8.1 products per assay) of which 105 were polymorphic $(86 \%)$. Using six multilocus probes, a total of 180 different bands were scored (an average of 30 bands/probe), of which $(97.77 \%)$ were polymorphic. These data are summarized in Table 3.

The marker index (MI) was used as an estimate of the utility of each system. MI is the product of the diversity index (DI) and effective multiplex ratio (EMR). The arithmetic mean of DI for polymorphic markers for each system is presented in Table 4. The highest level of polymorphism as measured by DI was detected using SSR-PCR (DI 0.957), followed by RFLP (0.936), SSR (0.79) and RAPD (0.744). Also presented in Table 4 is the arithmetic mean for EMR for each marker system. SSRs were assigned an EMR of 1 on the assumption that they reveal a single locus (which may not always be true). The average EMR is highest for RFLPs (28.68) which was slightly higher than that of ISSR-PCR (23.58) and sixfold that of RAPDs (4.81). The mean MI for each marker system calculated from the experimental data is also listed in Table 4. The distinctively higher EMRs for RFLPs and ISSR-PCR are reflected in the calculated MI for these two systems (26.67 and 23.58, respectively).

Spearman's rank correlations were used to rank the similarities generated using different marker assays and linear correlation regression analysis was used to compare individual similarity coefficients from two marker systems. The correlations are given in Table 5. Both tests indicated the best correspondence between RFLP and SSR (0.796), followed by SSR and ISSR-PCR (0.685) and RAPD and ISSR-PCR (0.682).

Silkworm germplasm can be divided into two gene pools, diapausing and non-diapausing, based on voltinism (number of generations in a year). The diapausing strains are mostly distributed in temperate zones and are characterized by longer larval life, higher body weight, higher fecundity, longer silk fibre and greater susceptibility to viral diseases as compared to the non-diapausing varieties, which are distributed mostly in tropical 
Fig. 1 Polymorphisms detected in 13 silkworm strains using (a) RAPD (OPA-03), (b) SSR (sat3513), (c) ISSR-PCR (GAT GCT GATA (CA)7) and (d) RFLP (pBmN138). (a)
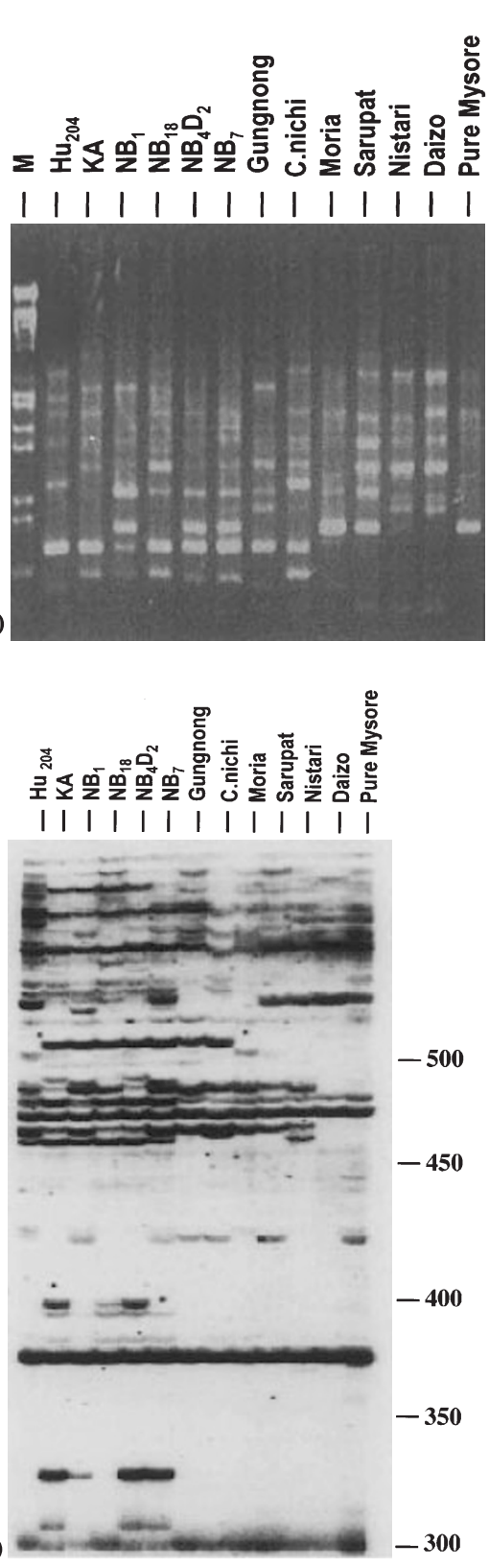

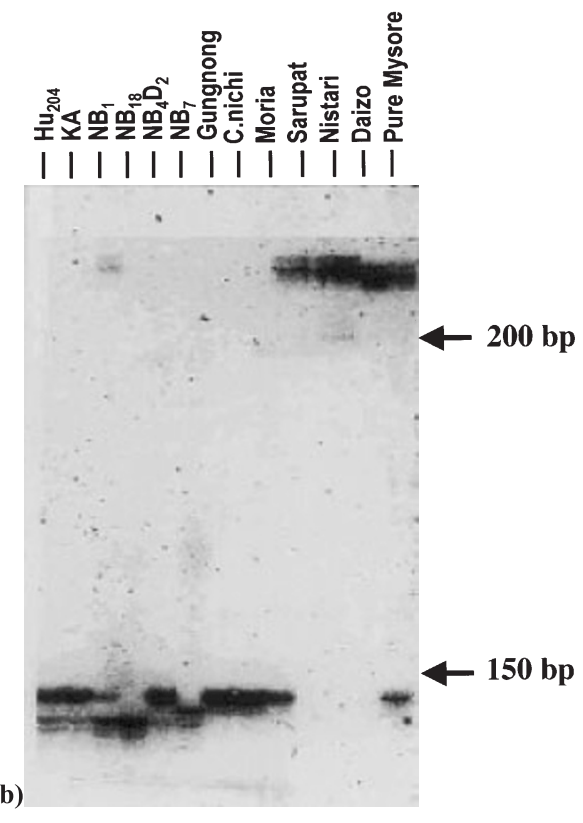

(b)

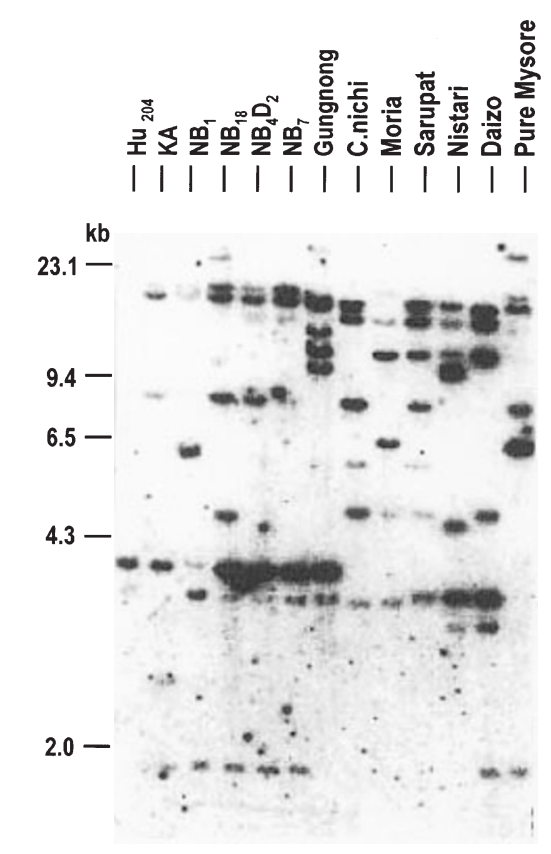

(d) countries, have shorter larval span, attain smaller body size, secrete short and thick fibre, and are resistant to viral diseases. Genetic similarities revealed by each of the marker systems were calculated using the Nei and Li coefficients and the dendrograms produced from similarity matrices for each marker system are shown in Figs 2(a)-2(d).

A clear separation of the two sets of diapausing and non-diapausing gene pools was evident using SSR,
RAPD and ISSR-PCR assays. Two RAPD primers, OPA-01 and OPA-02, generated products that were specific to all diapausing and non-diapausing strains; one of the SSR loci (sat 211) also produced diapause and non-diapause strain diagnostic alleles. Only in the SSR assay, the non-diapausing strain, $C$. nichi, was found clustered with the diapausing strains. Similar results were also obtained by Nagaraju et al. (1995) and Sharma et al. (1998) using a heterologous multilocus probe, 
Table 3 A summary of each type of marker assay performed on 13 silkworm strains

\begin{tabular}{llcccc}
\hline & $\begin{array}{c}\text { Total number } \\
\text { of assays }\end{array}$ & $\begin{array}{c}\text { Total number } \\
\text { of products }\end{array}$ & $\begin{array}{c}\text { Total polymorphic } \\
\text { products }\end{array}$ & $\begin{array}{c}\text { Mean number of } \\
\text { products per assay }\end{array}$ & $\begin{array}{c}\text { Percentage of } \\
\text { polymorphic products }\end{array}$ \\
\hline SSR & 15 (primer pairs) & 122 & 105 & 8.10 & 86.00 \\
Inter-SSR & 6 (primers) & 239 & 184 & 39.83 & 76.98 \\
RAPD & 40 (primers) & 216 & 204 & 5.40 & 94.44 \\
RFLP & 6 (probes) & 180 & 176 & 30.00 & 97.77 \\
\hline
\end{tabular}

Table 4 A summary of mean DI, EMR and MI for different marker assays of silkworms

\begin{tabular}{lccc}
\hline Marker assay & Mean DI & Mean EMR & Marker Index \\
\hline SSR & 0.795 & 1.0 & 0.795 \\
Inter-SSR & 0.957 & 23.6 & 22.570 \\
RAPD & 0.744 & 4.8 & 3.580 \\
RFLP & 0.930 & 28.7 & 26.670 \\
\hline
\end{tabular}

$\mathrm{Bkm}$. In addition, the cluster analysis produced a strong evidence for a subgroup based on similar pedigree $\left(\mathrm{NB}_{18}\right.$ and $\mathrm{NB}_{4} \mathrm{D}_{2}$ ), in all the four marker assays.

\section{Discussion}

To our knowledge, this is the first report of a comparison in animal genetics involving the four genetic marker systems. The current availability of several molecular techniques for the detection of polymorphisms has prompted us to explore their utility in the silkworm with a view to using them for genome mapping, germplasm screening and strain improvement programmes. Three PCR-based techniques, RAPD, SSR and ISSR-PCR, as well as RFLP methods, were examined for their ability to generate useful polymorphisms using 13 silkworm varieties. Each technique differed not only in its underlying principle, but also in the informativeness in regard to type and amount of polymorphisms detected. The highest level of polymorphism was detected using multilocus RFLP probes $(97.77 \%)$ and the lowest was associated with ISSRs $(76.8 \%)$. However, the ISSR revealed an average number of 39 bands per lane or per assay compared to eight bands for SSRs in the pooled DNA samples. Powell et al. (1996) introduced the concept of MI as an overall measure of efficiency of different marker assays. We utilized this concept to measure MI and DI in the silkworm. When the overall DIs of the four techniques were compared, ISSR had the highest value (0.957) followed closely by multilocus RFLPs (0.930).

The high MI as well as DI is a reflection of the efficiency of the ISSR-PCR and multilocus RFLP markers to simultaneously analyse a large number of bands rather than of the level of polymorphism detected. The results show that ISSR-PCR and multilocus RFLP markers are the most powerful of the four techniques for fingerprinting silkworm varieties. The large number of PCR products observed in the ISSRPCR assay is not surprising since the $B$. mori genome is abundant with dinucleotide repeat motifs, particularly CA repeats (Reddy et al., 1999b) and ISSR primers are designed to anchor such microsatellite motifs to amplify the genomic sequences lying between them. Many of the anonymous multilocus RFLP probes used in the present study are probably derived from genomic regions containing transposable elements or minisatellite-like sequences which account for several thousand copies per haploid genome of the silkworm (Nagaraju et al., 1995; Robertson \& Asplund, 1996). Although most ISSR loci are dominant, rather than codominant, ISSR-PCR markers offer several advantages over RFLPs for genotyping, the major one being the rapid production of a large number of markers in a cost-effective manner. Moreover, the ISSR markers offer higher reproducibility due to the use of longer primers and a higher annealing temperature than those used for RAPDs. Because of these advantages, we believe that the ISSR-

\begin{tabular}{|c|c|c|c|c|c|c|c|c|}
\hline & \multicolumn{2}{|c|}{ ISSR } & \multicolumn{2}{|c|}{ SSR } & \multicolumn{2}{|c|}{ RAPD } & \multicolumn{2}{|c|}{ RFLP } \\
\hline & SRC & $r^{2}$ & SRC & $r^{2}$ & SRC & $r^{2}$ & SRC & $r^{2}$ \\
\hline ISSR & - & - & & & & & & \\
\hline SSR & 0.685 & 0.294 & - & - & & & & \\
\hline RAPD & 0.682 & 0.411 & 0.679 & 0.325 & - & - & & \\
\hline RFLP & 0.612 & 0.430 & 0.796 & 0.286 & 0.66 & 0.558 & - & 一 \\
\hline
\end{tabular}

Table 5 Correlations obtained between the genetic similarities in silkworms calculated using ISSR, SSR, RAPD and RFLP techniques, based on comparison of similarity matrices (Spearman's rank correlation [SRC] and regression analysis) $r^{2}$ 


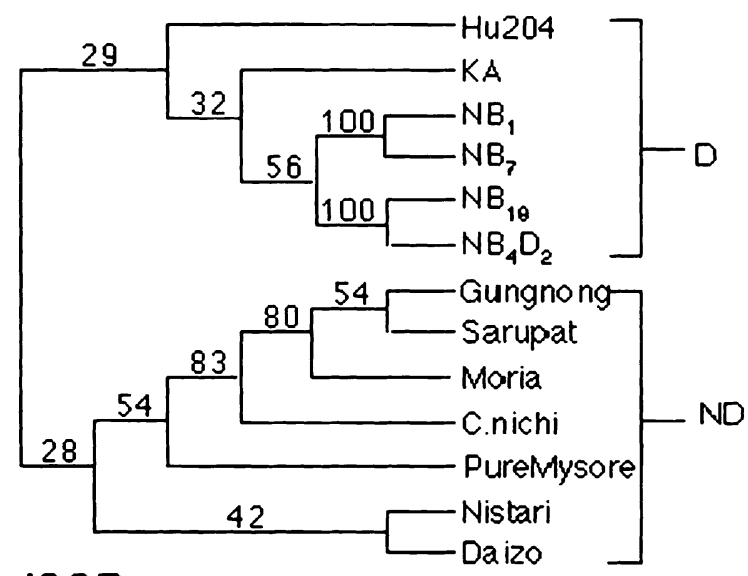

ISSR

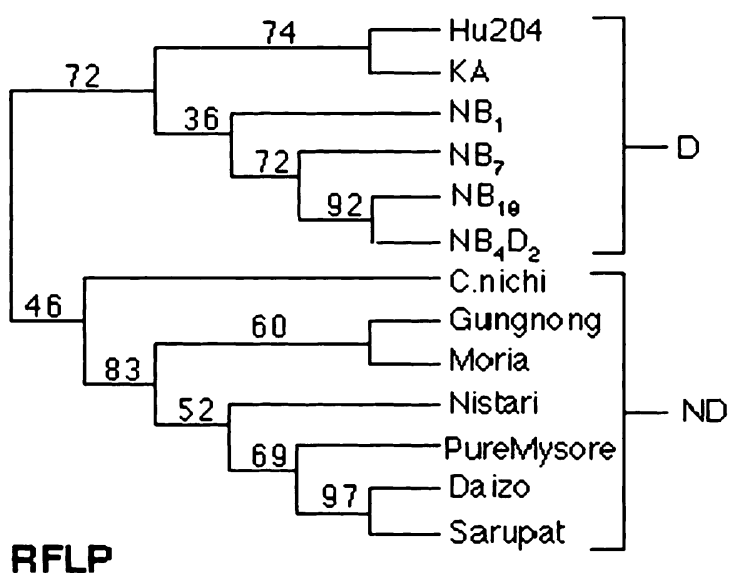

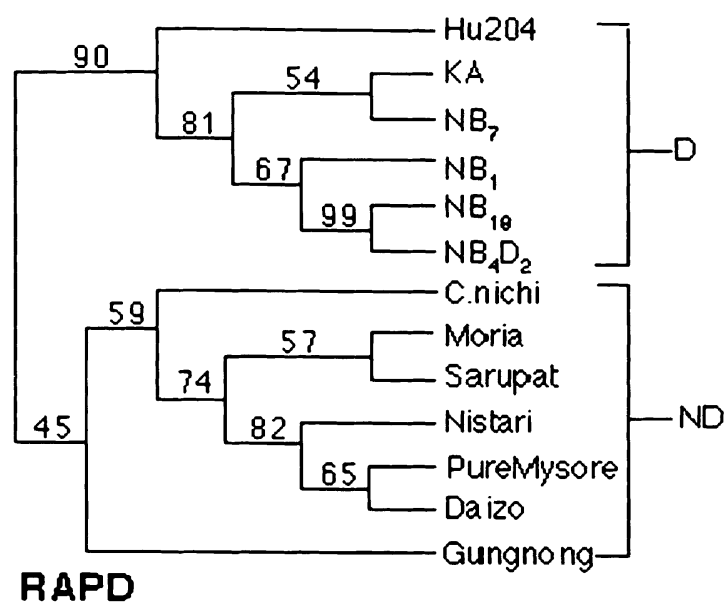

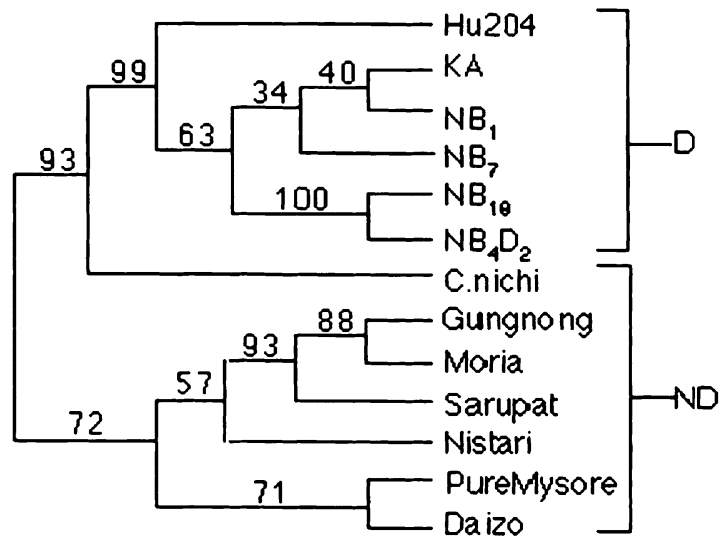

SSR

Fig. 2 Dendrograms generated from genetic similarity matrices calculated using Nei and Li coefficients for ISSR-PCR, RFLP, RAPD and SSR marker assays. D, diapausing silkworm strains; ND, non-diapausing silkworm strains. Numbers on the nodes indicate the number of times a particular branch was recorded per 100 bootstrap replications following 1000 replications.

PCR technique has great potential in silkworm breeding, germplasm evaluation and genetic mapping. Recently we have automated the ISSR-PCR assay by incorporating the fluorescent nucleotide in the PCR reaction and electrophoresing the PCR products on an ABI 377 automated sequencer. This method (called FISSR-PCR) requires very little quantity of template DNA (3-5 ng) and further enhances the sensitivity and resolution of the markers, rendering the method very suitable for high throughput genotyping and genetic mapping experiments (Nagaraju et al. in preparation).

The multilocus RFLP probes also offer features such as high reproducibility and unambiguous marker scoring similar to ISSR-PCR, but require radioactive labelling and hybridization, which are labour intensive and are not cost-effective because of the large quantities of DNA needed for blotting and the longer preparation time. On the other hand both ISSR-PCR and multilocus markers are scored as dominant markers since neither of them reflect the allelic status of the polymorphic bands, and hence homozygosity levels cannot be determined in population studies. Although the RAPD technique is widely used, problems of reliability and repeatability have been reported. Many factors such as concentration of $\mathrm{Mg}^{2+}$, quality of the template, thermal cycler, and the source of polymerase affect amplification. Although in our study, RAPD markers reliably discriminated the silkworm varieties, the technique has to be approached with caution. In these aspects, SSRs are more useful than the other three techniques since they reveal codominantly inherited, multiallelic products of loci that can be readily used for genetic diversity, pedigree evaluation and genetic mapping. However, the SSR technology is expensive considering that prior sequence information is required to design the locus-specific primers. But the advantages that they are robust and are amenable to automation compensate the cost inputs and increase the cost-benefit ratio. 
The major goals envisaged for molecular markers in the silkworm are the construction of linkage maps to understand the genetics of simple as well as complex traits, and for their use in marker-assisted selection. In this respect, SSR markers should serve as markers of choice. Studies have shown that the silkworm genome contains $(\mathrm{CA})_{\mathrm{n}}$ and $(\mathrm{GA})_{\mathrm{n}}$ repeats at almost every $40 \mathrm{~kb}$ and $100 \mathrm{~kb}$, respectively (Reddy et al., 1999b). Such abundantly distributed microsatellite loci would provide the required markers for intensive molecular mapping of the silkworm genome. More than 3000 silkworm varieties maintained in different countries, and which represent an array of differences for various traits, remain to be characterized genetically. In countries like China, India, Thailand, South Korea, and Japan, where sericulture is being practised, silkworm breeders develop new silkworm varieties which must be characterized for their DNA profiles for production of heterotic hybrids, protection of intellectual property rights and other statutory, regulatory and legal applications. Based on the observed EMR, ISSR-PCR is best suited for generation of the volume of information required for performance of such a task.

\section{Acknowledgements}

We thank Marian R Goldsmith for critical reading of the manuscript and useful suggestions and $\mathrm{Mr} \mathrm{B}$. P. Nair for statistical analysis of different marker systems.

Financial support by Department of Biotechnology, Govt. of India to JN is gratefully acknowledged.

\section{References}

BISHOP, D. AND SKOLNICK, M. H. 1980. Numerical considerations for linkage studies using polymorphic DNA markers in humans. Banbury Report 4: Cancer incidence in defined populations, pp. 421-433. Cold Spring Harbor Laboratory, Cold Spring Harbor, NY.

BLACK, W. C., IV. 1993. PCR with arbitrary primers: approach with care. Insect Mol. Biol., 2, 1-6.

BOTSTEIN, D., WHITE, R. L., SKOLNICK, M. AND DAVIS, R. W. 1980. Construction of genetic linkage map in man using restriction length polymorphisms. Am. J. Hum. Genet., 32, 314-331.

DIETRICH, W., KATZ, M., LINCOLN, S. E., SHIN, H. S. ET AL. 1992. A genetic map of the mouse suitable for typing intraspecific crosses. Genetics, 131, 423-447.

hamadA, H., PETRINO, M. G. AND KAKunAga, T. 1982. A novel repeated element with Z-DNA forming potential is widely found in evolutionarily diverse eukaryotic genomes. Proc. Natl. Acad. Sci. U.S.A., 79, 6465-6469.

NAGARAJA, G. M. AND NAGARAJU, J. 1995. Genome fingerprinting in silkworm, Bombyx mori using random arbitrary primers. Electrophoresis, 16, 1633-1638.
NAGARAJU, J., SHARMA, A., SETHURAMAN, B. N., RAO, G. V. ET $A L$. 1995. DNA fingerprinting in silkworm Bombyx mori using banded krait minor satellite DNA-derived probe. Electrophoresis, 16, 1639-1642.

NEI, M. AND LI, W. H. 1979. Mathematical model for studying genetic variation in terms of restriction endonucleases. Proc. Natl. Acad. Sci. USA., 76, 5269-5273.

POWELl, W., MORGANTE, M., ANDRE, C., HANAFEY, M. ET AL. 1996. The comparison of RFLP, RAPD, AFLP and SSR (microsatellite) markers for germplasm analysis. Mol. Breed., 2, 225-238.

PROMBOON, A., SHIMADA, T., FUZIWARA, H. AND KOBAYASHI, M. 1995. Linkage map of random amplified polymorphic DNAs (RAPDs) in the silkworm, Bombyx mori. Genet. Res., 66, 1-7.

REDDY, K. D., NAGARAJU, J. AND ABRAHAM, E. G. 1999a. Genetic characterization of the silkworm, Bombyx mori by simple sequence repeat (SSR)-anchored PCR. Heredity, 83, 681-687.

ReDDY, K. D., ABRAhAM, E. G. AND Nagaraju, J. 1999b. Microsatellites in the silkworm, Bombyx mori: abundance, polymorphism and strain characterization. Genome, 42, 10571065.

ROBERTSON, H. M. AND ASPLUND, M. 1996. Bmmarl: a basal lineage of the mariner family of transposable elements in the silkmoth, Bombyx mori. Insect Biochem. Mol. Biol., 8-9, 945-954.

SAMBROOK, J., FRITSCH, E. F. AND MANIATIS, T. C. 1989. Molecular Cloning: A Laboratory Manual, 2nd edn. Cold Spring Harbor Laboratory Press, Cold Spring Harbor, NY. SHARMA, A., NIPHADKAR, M. P., KATHIRVEL, P., NAGARAJU, J. ET $A L$. 1998. DNA fingerprint variability within and among the silkworm Bombyx mori varieties and estimation of their genetic relatedness using Bkm-derived probe. J. Hered., 90, 315-319.

SHI, J., HECKEL, D. G. AND GOLDSMITH, M. R. 1995. A genetic linkage map for the domesticated silkworm, Bombyx mori, based on restriction fragment length polymorphisms. Genet. Res., 66, 109-126.

TAUTZ, D. AND RENZ, M. 1984. Simple sequences are ubiquitous repetitive components of eukaryotic genomes. Nucl. Acids Res., 12, 4127-4138.

TAUTZ, T., TRICK, M. AND DOVER, G. A. 1986. Cryptic simplicity in DNA is a major source of DNA variation. Nature, 332, 652-658.

Vos, P., HOGERS, R., BLEEKER, M., REIJANS, M. ET AL. 1995. AFLP: a new technique for DNA fingerprinting. Nucl. Acids Res., 23, 4407-4414.

WEBER, J. L. AND MAY, P. E. 1989. Abundant class of human DNA polymorphisms which can be typed using the polymerase chain reaction. Am. J. Hum. Genet., 44, 388-396.

WELSH, J. AND MCCLELlAND, M. 1990. Fingerprinting genomes using PCR with arbitrary primers. Nucl. Acids Res., 189, 7213-7218.

WILLIAMS, J. G. K., KUBliK, A. R., LIVAK, K. J., RAFALSKI, J. A. ET $A$ L. 1990. DNA polymorphisms amplified by arbitrary primers are useful as genetic markers. Nucl. Acids Res., 18, 6531-6535. 
WU, K. S., JONES, R., DANNEBERGER, L. AND SCOLNIK, P. A. 1994. Detection of microsatellite polymorphisms without cloning. Nucl. Acids Res., 22, 3257-3258.

YAP, I. AND NELSON, R. J. 1996. WINBOOT: A program for performing bootstrap analysis of binary data to determine the confidence limits of UPGMA-based dendrograms. IRRI Discussion Paper Series No. 14, International Rice Research Institute, Manila, Philippines.
YASUKOCHI, Y. 1998. A dense genetic map of the silkworm, Bombyx mori covering all chromosomes based on 1018 molecular markers. Genetics, 150, 1513-1625.

ZIETKIECWICZ, E., RAFALSKI, A. AND LABUDA, D. 1994. Genome fingerprinting by simple sequence repeat (SSR)-anchored polymerase chain reaction amplification. Genomics, 20, 176-183. 